\title{
Bioinformatic prospecting and phylogenetic analysis reveals 94 undescribed circular bacteriocins and key motifs
}

\author{
Ben Vezina, Bernd H. A. Rehm and Andrew T. Smith*
}

\begin{abstract}
Background: Circular bacteriocins are antimicrobial peptides produced by bacteria with a $\mathrm{N}$ and $\mathrm{C}$ termini ligation. They have desirable properties such as activity at low concentrations along with thermal, pH and proteolytic resistance. There are twenty experimentally confirmed circular bacteriocins as part of bacteriocin gene clusters, with transport, membrane and immunity proteins. Traditionally, novel antimicrobials are found by testing large numbers of isolates against indicator strains, with no promise of corresponding novel sequence.
\end{abstract}

Results: Through bioprospecting publicly available sequence databases, we identified ninety-nine circular bacteriocins across a variety of bacteria bringing the total to 119. They were grouped into two families within class I modified bacteriocins ( $i$ and ii) and further divided into subfamilies based on similarity to experimentally confirmed circular bacteriocins. Within subfamilies, sequences overwhelmingly shared similar characteristics such as sequence length, presence of a polybasic region, conserved locations of aromatic residues, C and N termini, gene clusters similarity, translational coupling and hydrophobicity profiles. At least ninety were predicted to be putatively functional based on gene clusters. Furthermore, bacteriocins identified from Enterococcus, Staphylococcus and Streptococcus species may have activity against clinically relevant strains, due to the presence of putative immunity genes required for expression in a toxin-antitoxin system. Some strains such as Paenibacillus larvae subsp. pulvifaciens SAG 10367 contained multiple circular bacteriocin gene clusters from different subfamilies, while some strains such as Bacillus cereus BCE-01 contained clusters with multiple circular bacteriocin structural genes.

Conclusions: Sequence analysis provided rapid insight into identification of novel, putative circular bacteriocins, as well as conserved genes likely essential for circularisation. This represents an expanded library of putative antimicrobial proteins which are potentially active against human, plant and animal pathogens.

Keywords: Antimicrobial, Bioinformatics, Pathogen, Cluster analysis, Hydrophobicity, Immunity, Antibiotics, Gram positive

\section{Background}

Circular bacteriocins are part of class I modified [1] ribosomally produced antimicrobial peptides with a covalent peptide bond between the $\mathrm{N}$ and $\mathrm{C}$ termini $[2,3]$. The circularisation of the molecule improves thermostability, $\mathrm{pH}$ tolerance and proteolytic resistance [4], under

\footnotetext{
* Correspondence: andrew.smith@griffith.edu.au

Centre for Cell Factories and Biopolymers, Griffith Institute for Drug Discovery, Griffith University, Nathan, Australia
}

which conditions most other proteins would be denatured or inactivated. Linearising or nicking circular bacteriocins hampers these intrinsic properties as well as causing a significant reduction in anti-microbial potency [5-7]. They have been shown to work by binding to the cell membrane and creating pores, which act as nonselective ion channels causing cell death [8-11]. Receptor molecules binding circular bacteriocins may also be involved, as demonstrated by garvicin ML targeting the maltose ABC transporter [12].

C C The Author(s). 2020 Open Access This article is licensed under a Creative Commons Attribution 4.0 International License, which permits use, sharing, adaptation, distribution and reproduction in any medium or format, as long as you give appropriate credit to the original author(s) and the source, provide a link to the Creative Commons licence, and indicate if changes were made. The images or other third party material in this article are included in the article's Creative Commons licence, unless indicated otherwise in a credit line to the material. If material is not included in the article's Creative Commons licence and your intended use is not permitted by statutory regulation or exceeds the permitted use, you will need to obtain permission directly from the copyright holder. To view a copy of this licence, visit http://creativecommons.org/licenses/by/4.0/ The Creative Commons Public Domain Dedication waiver (http://creativecommons.org/publicdomain/zero/1.0/) applies to the data made available in this article, unless otherwise stated in a credit line to the data. 
Bacteriocins have many advantages over traditional antimicrobials such as antibiotics. Bacteriocin resistance has been studied but it appears to occur at varying frequencies [13], indicating each bacteriocin should be tested for resistance before clinical/food use. Because bacteriocins are encoded, it means they can be genetically engineered and targeted towards specific organisms $[14,15]$. Due to these characteristics, there is also considerable scope for use in anti-spoilage and food-safety applications.

Circular bacteriocins are class I bacteriocins which can be divided into two families, $i$ and ii based on sequence identity $[16,17]$. Table 1 shows the list of experimentally confirmed circular bacteriocins and their characteristics. Class I circular bacteriocins are short sequences (58-70 amino acids in length), four (five in the case of AS-48 and BacA) helical segments that enclose a tightly packed hydrophobic core, a saposin fold, no cysteine pairs, and all (except butyrivibriocin AR10) contain a polybasic region involved in binding to target cell membranes [11, 30, 34, 35].

Circular bacteriocins are usually produced by a gene cluster or operon consisting of 4-10 genes. The mechanism of circularisation and roles of each gene within clusters have not yet been completely elucidated [17, 36], though annotation and mutagenesis studies have provided insight into this [7, 37]. A pre-peptide encoded by the bacteriocin structural gene is produced, followed by signal sequence/leader peptide cleavage. This mature peptide is then able to be either circularised within the cell then secreted which has been shown for leucocyclin $\mathrm{Q}$ [38], or secreted and then circularised [39]. The genes involved and the process are not well understood, and it's possible that different pathways exist for different circular bacteriocins. Circularisation appears contingent on hydrophobic $\mathrm{N}$ and $\mathrm{C}$ termini residues along with the signal sequence, which is required for correct mature peptide processing [40].

Circular bacteriocin gene clusters are often constituted of overlapping genes, demonstrating a tight organisational structure or genes which depend upon the ribosomal binding site of upstream genes. This indicates expression is regulated by translational coupling [41]. All of the currently identified circular bacteriocin gene clusters contain at least two genes that are translationallycoupled (Table 1).

There are twenty experimentally confirmed circular bacteriocins. Evolutionary-based approaches such as sequence alignments, phylogenetics and gene cluster analysis can provide insight and allow novel identification. This study has identified many new and unmentioned putative circular bacteriocins based on sequence similarity from publicly available sequence data. These putative circular bacteriocins were analysed for characteristics commonly found in circular bacteriocins. Figure 1 shows the workflow detailed in this study.

\section{Results \\ Identification and characteristics of putative circular bacteriocins}

This study has identified ninety-nine putative circular bacteriocins within a range of microorganisms. Bringing the total known circular bacteriocins to 119 (Fig. 2, Fig. S1). Five of these have been previously bioinformatically identified [30] but were included in the analyses regardless. Figure S1 contains detailed information about each identified circular bacteriocin, characteristics, strain information and accession numbers. As signal sequences can be highly species specific [11, 42], they were not used for identification of putative circular bacteriocins. Signal sequences are essential for correct folding, circularisation and bioactivity of circular bacteriocins [40]. By removing them from database mining identification of distantly-related putative circular bacteriocins was based on functional antimicrobial protein sequence, rather than irrelevant signal sequence. While some putative circular bacteriocins were annotated correctly, many were unannotated or annotated as branched-chain amino acid aminotransferases which are involved in amino acid catabolism [43], despite having high similarity and sequence motifs to the mature sequences of known circular bacteriocins.

None contained disulphide bonds. Cysteine residues existed only as single residues in 10/119 of the putative and experimentally confirmed sequences, indicating they are not present for disulphide bond formation (Fig. S1). Almost every putative and experimentally-confirmed circular bacteriocin contained a polybasic region. The paracyclicin and butyrivibriocin AR10 subfamilies were distinct from this trend, as they contained 1-2 basic residues. Both paracyclicin and butyrivibriocin AR10 have been experimentally confirmed. The circular bacteriocin from Alkalibacterium AK22 (NZ_JANL01000003.1) did not contain any basic residues. $96.6 \%$ of the sequences identified contained aromatic residues, which were locationally-conserved (Fig. S1, Table 3). Only Bacillus krulwichiae AM31D, Virgibacillus proomii V-P and Alkalibacterium AK22 contained circular bacteriocin sequences without aromatic residues.

Two Paenibacillus larvae strains each harboured two independent putative circular bacteriocins clusters. Paenibacillus larvae subsp. pulvifaciens SAG 10367 (NZ_ CP020557) contained amylocyclicin-like and uberolysinlike clusters, while Paenibacillus larvae subsp. larvae ERIC_I (NZ_CP019651.1) harboured AS-48-like and uberolysin-like clusters.

Table 2 shows the list of bacteriocins identified which may be active against the WHO's global priority list of 


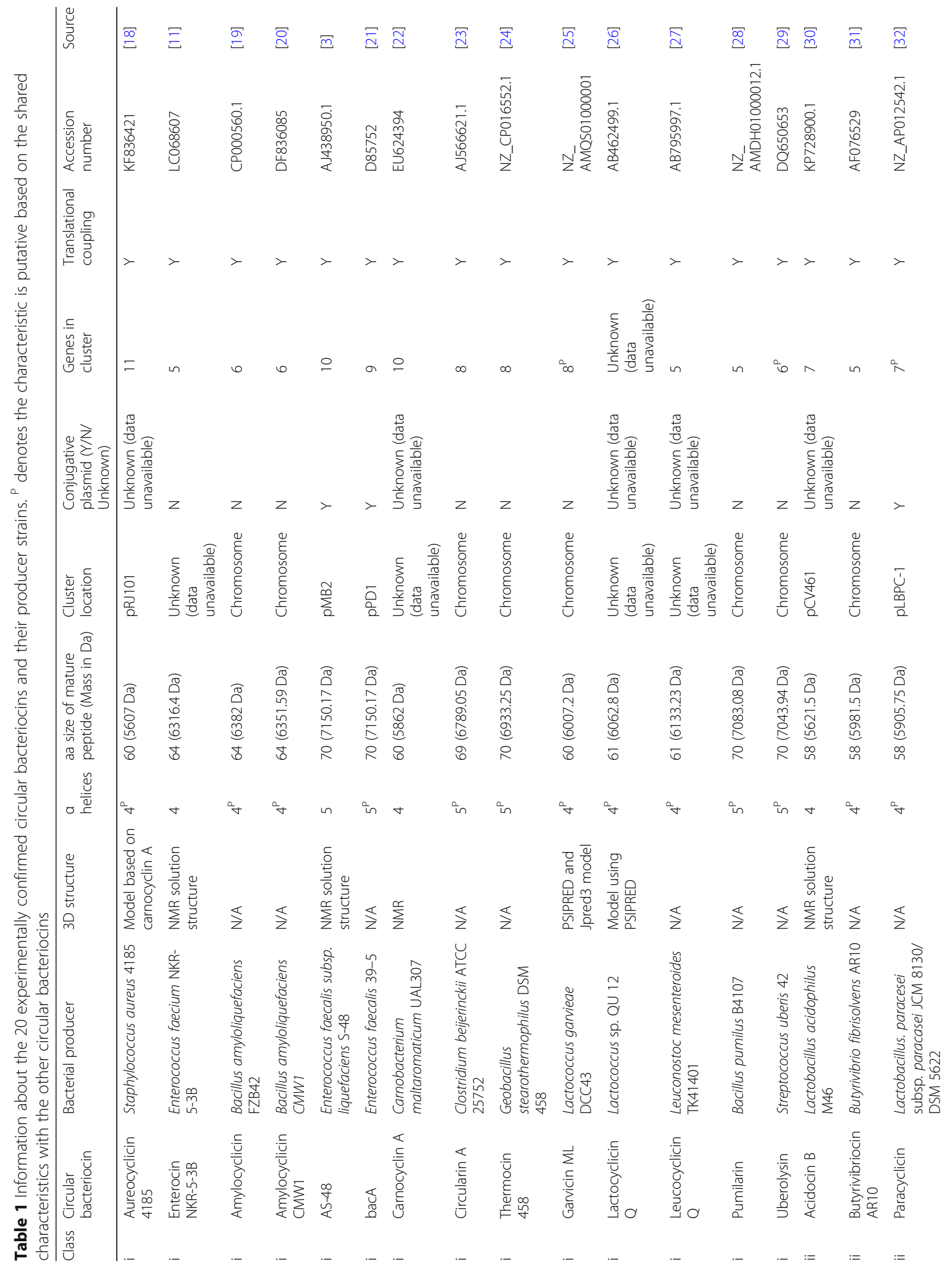




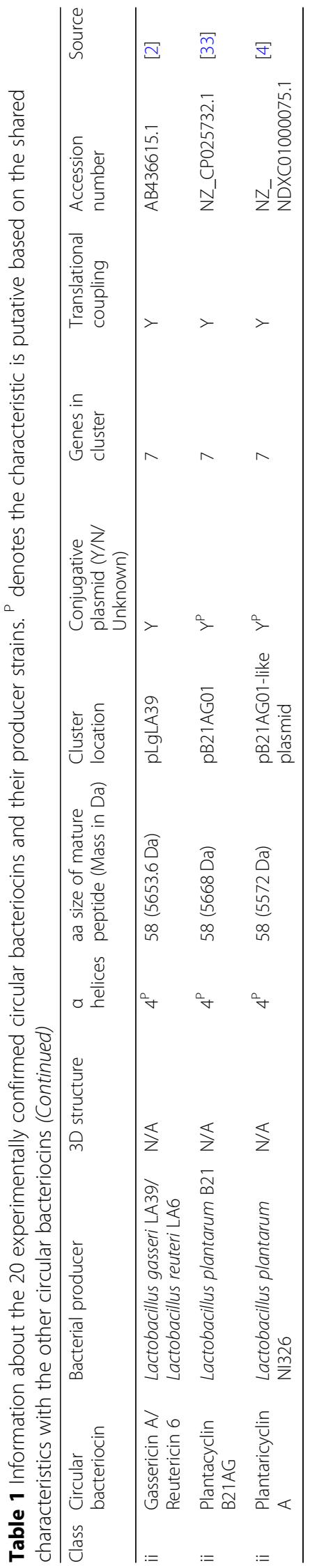


Identify experimentally confirmed mature bacteriocin sequences and screen publicly available databases

MAKEFGIPAAVAGTVLNVVEAGGWVTTIVSILTAVGSGGLSLLAAAGRESIKAYLKKEIKKKGKRAVIAW
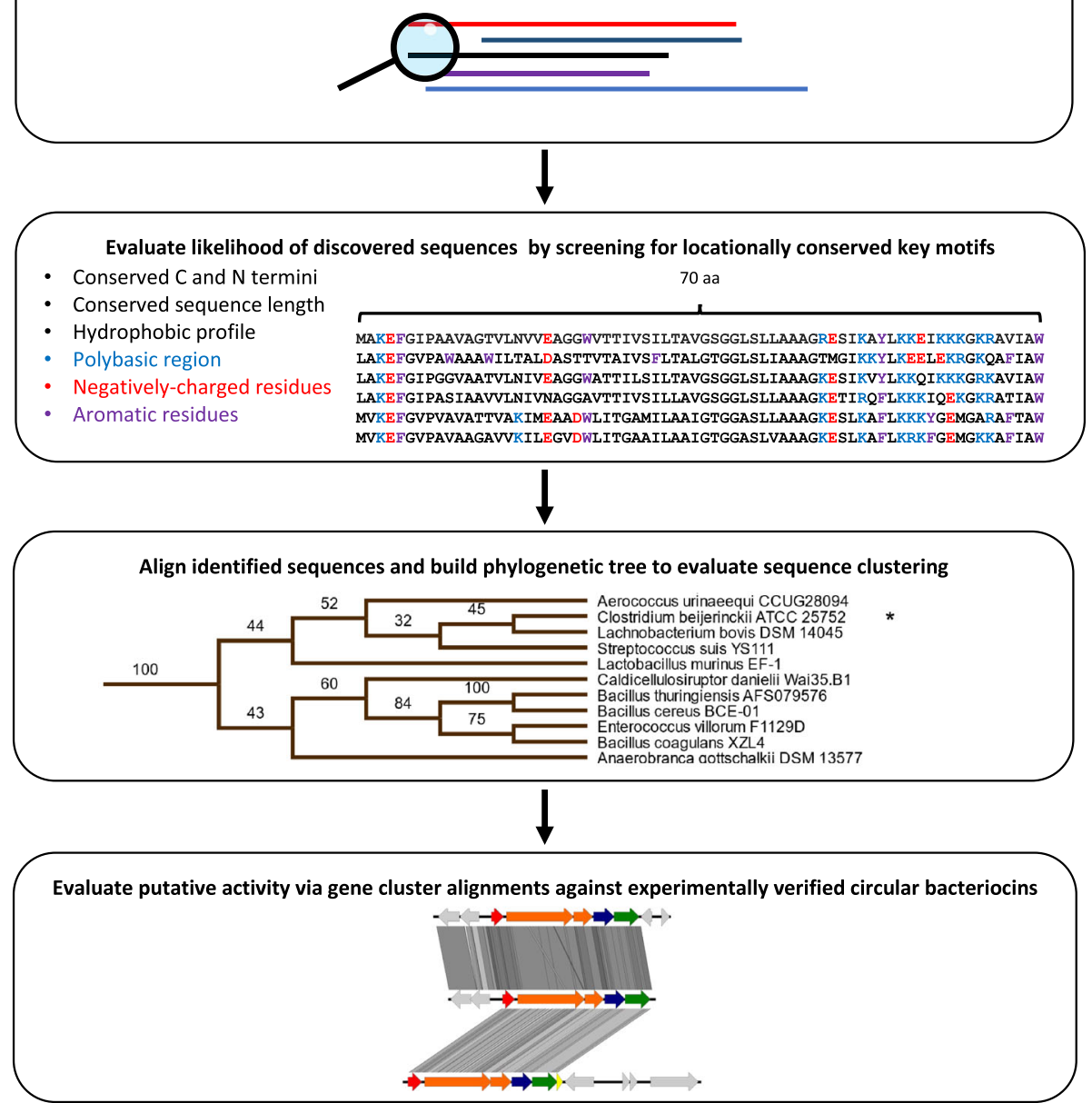

Fig. 1 Graphical representation of the analysis workflow leading from sequence acquisition to the classification and evaluation of discovered putative circular bacteriocins

antibiotic resistant bacteria due to the presence of putative immunity genes within the gene clusters [44].

\section{Phylogenetics of circular bacteriocins}

Based on the sequence analysis of bacteriocins, there appears to be two different families of class I circular bacteriocins, family $\mathrm{i}$ and ii, each cluster with bootstrap values of 100 [16, 17] (Fig. 2, Fig. S2). Out of the 119 sequences, 89 (74.8\%) are part of family i while 29 (24.4\%) are from family ii (Fig. S2, Table 3). However, there is considerable sequence divergence within these families, with family i demonstrating a wide variety of sequence lengths and compositions. Therefore, the most appropriate way to classify these sequences was to separate them based on their most closely-related experimentally confirmed circular bacteriocin. In some cases such as streptocyclin, divergence was considered too high (based on bootstrap values) and new subfamilies were coined using the 'cyclin' suffix.

Due to phylogenetic ambiguity and divergence of the identified circular bacteriocin sequences, it was inappropriate to classify each putative circular bacteriocin into currently identified/characterised subfamilies. To remedy this, new circular bacteriocin subfamilies were proposed and named including streptocyclin, akalicyclin, krulwicyclin, bacillocyclin and venezuelacyclin (Fig. S1).

Family i was composed of the circularin, lactocyclin/ leucocyclin, bacillocyclin, AS-48, amylocyclin, enterocin NKR-5-3B, uberolysin, aureocyclicin 4185/garvicin ML, venezuelacyclin, krulwicyclin and carnocyclin A subfamilies. Family ii were composed of the paracyclicin, akalicyclin, streptocyclin, butyrivibriocin AR10, gassericin A/ acidocin B and plantaricyclin/plantacyclin subfamilies. Due to sequence similarity and phylogenetic branch position, several experimentally confirmed circular 


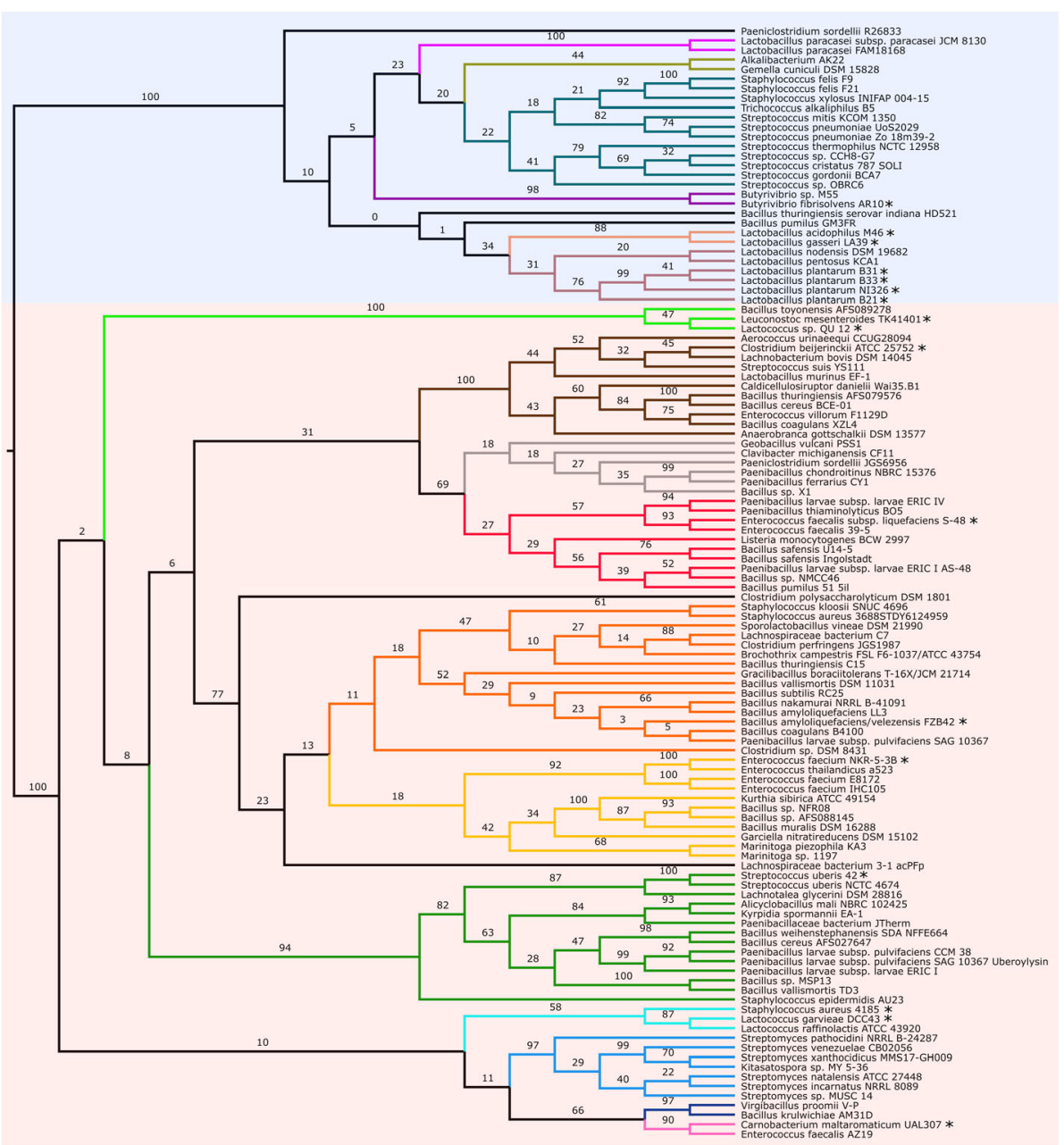

Fig. 2 Phylogenetic tree showing the subfamilies of circular experimentally confirmed and putative bacteriocins. *Experimentally-confirmed. Transparent red overlay shows family i. Transparent blue overlay shows family ii. Red: AS-48 subfamily. Orange: amylocyclicin subfamily. Yellow: enterocin NKR-5-3B subfamily. Green: uberolysin subfamily. Light: aureocyclicin 4185/garvicin ML subfamily. Blue: putative venezuelacyclin subfamily. Dark blue: putative krulwicyclin subfamily. Pink: carnocyclin subfamily. Fuschia: paracyclicin subfamily. Gold: alkalicyclin subfamily. Teal: streptocyclin subfamily. Purple: butyrivibriocin AR10 subfamily. Peach: gassericin A/acidocin B subfamily. Brown: plantaricyclin/plantacyclin subfamily. Light green: lactocyclin/leucocyclin subfamily. Dark brown: circularin family. Grey: putative bacillocyclin subfamily. Black shows any putative circular bacteriocins which are too distinct to fit within the proposed subfamilies. Geobacillus stearothermophilus DSM 458 not used in phylogenetic tree

bacteriocins were classified within the same subfamily. They included aureocyclicin 4185 and garvicin ML (61.4\% similarity), lactocyclin and leucocyclin (82\% similarity), gassericin A and acidocin B (100\% similarity), plantaricyclin and plantacyclin ( $94.8 \%$ similarity). Some of these subfamilies will most likely fracture into clearer, distinct subfamilies as more sequences become available. Several putative circular bacteriocins were found on lone phylogenetic branches and did not fit into subfamilies and were not classified beyond the familial level.

\section{Hydrophobicity of mature circular bacteriocins}

Analysis of hydrophobicity profiles suggested two major profiles (Fig. 3), with a few exceptions (Fig. S3). This gave further evidence that the putative sequences identified were most likely circular bacteriocins. The two major hydrophobicity profiles of the circular bacteriocins matched the phylogenetic family classifications of family i and ii (Fig. 3). It appears, despite sequence divergence within families, residues are mutating to residues which maintain the hydrophobic profile of the protein. In general, the $\mathrm{N}$ terminus of class I i tended to have a variable hydrophobic profile, reflecting the sequence divergence and residue length differences within the family.

Both families have similar regions within the hydrophobicity profiles, despite the sequence variability within and between them. In general they are considerably hydrophobic. The $\mathrm{C}$ and $\mathrm{N}$ termini of every sequence 
Table 2 List of circular bacteriocins identified with potential activity against clinically relevant isolates as part of the WHO's Global priority list of antibiotic-resistant bacteria to guide research, discovery, and development of new antibiotics [44]

\begin{tabular}{|c|c|c|c|c|}
\hline $\begin{array}{l}\text { Identified } \\
\text { previously/in this } \\
\text { study }\end{array}$ & $\begin{array}{l}\text { Pathogen potentially } \\
\text { susceptible }\end{array}$ & Bacteriocin producer & $\begin{array}{l}\text { Experimental anti-bacterial activity against clinically relevant } \\
\text { bacteria }\end{array}$ & Source \\
\hline \multirow[t]{5}{*}{$\begin{array}{l}\text { Identified } \\
\text { previously }\end{array}$} & Enterococcus faecium & $\begin{array}{l}\text { Enterococcus faecalis 39- } \\
5\end{array}$ & S. aureus, E. faecalis, E. faecium, S. agalactiae, S. sanguis & [45] \\
\hline & Enterococcus faecium & $\begin{array}{l}\text { Enterococcus faecalis } \\
\text { subsp. liquefaciens S-48 }\end{array}$ & S. faecalis S-47, Escherichia coli U-9, E. faecalis OGIX & $\begin{array}{l}{[46,} \\
47]\end{array}$ \\
\hline & Enterococcus faecium & $\begin{array}{l}\text { Enterococcus faecium } \\
\text { NKR-5-3B }\end{array}$ & B. coagulans, B. subtilis, L. lactis ssp. lactis, L. sakei ssp. sakei & [48] \\
\hline & Staphylococcus aureus & $\begin{array}{l}\text { Staphylococcus aureus } \\
4185\end{array}$ & B. cereus, B. coagulans, B. licheniformis, L. monocytogenes, M. luteus & $\begin{array}{l}{[49,} \\
50]\end{array}$ \\
\hline & $\begin{array}{l}\text { Streptococcus } \\
\text { pneumoniae/Group A/ } \\
\text { Group B }\end{array}$ & Streptococcus uberis 42 & $\begin{array}{l}\text { E. faecalis, E. hirae, M. luteus, S. aureus, S. agalactiae, S. salivarius, S. } \\
\text { pyogenes, S. equisimilis, S. dysgalactiae, S. anginosus }\end{array}$ & [29] \\
\hline \multirow[t]{18}{*}{$\begin{array}{l}\text { Identified in this } \\
\text { study }\end{array}$} & Enterococcus faecium & $\begin{array}{l}\text { Enterococcus villorum } \\
\text { F1129D }\end{array}$ & N/A & $\begin{array}{l}\text { This } \\
\text { study }\end{array}$ \\
\hline & Enterococcus faecium & $\begin{array}{l}\text { Enterococcus thailandicus } \\
\text { a523 }\end{array}$ & N/A & $\begin{array}{l}\text { This } \\
\text { study }\end{array}$ \\
\hline & Enterococcus faecium & $\begin{array}{l}\text { Enterococcus faecium } \\
\text { E8172 }\end{array}$ & N/A & $\begin{array}{l}\text { This } \\
\text { study }\end{array}$ \\
\hline & Enterococcus faecium & $\begin{array}{l}\text { Enterococcus faecium } \\
\text { IHC105 }\end{array}$ & N/A & $\begin{array}{l}\text { This } \\
\text { study }\end{array}$ \\
\hline & Enterococcus faecium & $\begin{array}{l}\text { Enterococcus faecalis } \\
\text { AZ19 }\end{array}$ & N/A & $\begin{array}{l}\text { This } \\
\text { study }\end{array}$ \\
\hline & Staphylococcus aureus & Staphylococcus felis F9 & N/A & $\begin{array}{l}\text { This } \\
\text { study }\end{array}$ \\
\hline & Staphylococcus aureus & Staphylococcus felis F21 & N/A & $\begin{array}{l}\text { This } \\
\text { study }\end{array}$ \\
\hline & Staphylococcus aureus & $\begin{array}{l}\text { Staphylococcus xylosus } \\
\text { INIFAP 004-15 }\end{array}$ & N/A & $\begin{array}{l}\text { This } \\
\text { study }\end{array}$ \\
\hline & Staphylococcus aureus & $\begin{array}{l}\text { Staphylococcus kloosii } \\
\text { SNUC } 4696\end{array}$ & N/A & $\begin{array}{l}\text { This } \\
\text { study }\end{array}$ \\
\hline & Staphylococcus aureus & $\begin{array}{l}\text { Staphylococcus aureus } \\
\text { 3688STDY6124959 }\end{array}$ & N/A & $\begin{array}{l}\text { This } \\
\text { study }\end{array}$ \\
\hline & Staphylococcus aureus & $\begin{array}{l}\text { Staphylococcus } \\
\text { epidermidis AU23 }\end{array}$ & N/A & $\begin{array}{l}\text { This } \\
\text { study }\end{array}$ \\
\hline & $\begin{array}{l}\text { Streptococcus } \\
\text { pneumoniae/Group A/ } \\
\text { Group B }\end{array}$ & $\begin{array}{l}\text { Streptococcus uberis } \\
\text { NCTC } 4674\end{array}$ & N/A & $\begin{array}{l}\text { This } \\
\text { study }\end{array}$ \\
\hline & $\begin{array}{l}\text { Streptococcus } \\
\text { pneumoniae/Group A/ } \\
\text { Group B }\end{array}$ & Streptococcus suis YS111 & N/A & $\begin{array}{l}\text { This } \\
\text { study }\end{array}$ \\
\hline & $\begin{array}{l}\text { Streptococcus } \\
\text { pneumoniae/Group A/ } \\
\text { Group B }\end{array}$ & Streptococcus sp. OBRC6 & N/A & $\begin{array}{l}\text { This } \\
\text { study }\end{array}$ \\
\hline & $\begin{array}{l}\text { Streptococcus } \\
\text { pneumoniae/Group A/ } \\
\text { Group B }\end{array}$ & $\begin{array}{l}\text { Streptococcus gordonii } \\
\text { BCA7 }\end{array}$ & N/A & $\begin{array}{l}\text { This } \\
\text { study }\end{array}$ \\
\hline & $\begin{array}{l}\text { Streptococcus } \\
\text { pneumoniae/Group A/ } \\
\text { Group B }\end{array}$ & $\begin{array}{l}\text { Streptococcus cristatus } \\
\text { 787_SOLI }\end{array}$ & N/A & $\begin{array}{l}\text { This } \\
\text { study }\end{array}$ \\
\hline & $\begin{array}{l}\text { Streptococcus } \\
\text { pneumoniae/Group A/ } \\
\text { Group B }\end{array}$ & $\begin{array}{l}\text { Streptococcus sp. CCH8- } \\
\text { G7 }\end{array}$ & N/A & $\begin{array}{l}\text { This } \\
\text { study }\end{array}$ \\
\hline & $\begin{array}{l}\text { Streptococcus } \\
\text { pneumoniae/Group A/ }\end{array}$ & $\begin{array}{l}\text { Streptococcus mitis } \\
\text { KCOM } 1350\end{array}$ & N/A & $\begin{array}{l}\text { This } \\
\text { study }\end{array}$ \\
\hline
\end{tabular}


Table 2 List of circular bacteriocins identified with potential activity against clinically relevant isolates as part of the WHO's Global priority list of antibiotic-resistant bacteria to guide research, discovery, and development of new antibiotics [44] (Continued)

\begin{tabular}{|c|c|c|c|c|}
\hline \multirow[t]{5}{*}{$\begin{array}{l}\text { Identified } \\
\text { previously/in this } \\
\text { study }\end{array}$} & $\begin{array}{l}\text { Pathogen potentially } \\
\text { susceptible }\end{array}$ & Bacteriocin producer & $\begin{array}{l}\text { Experimental anti-bacterial activity against clinically relevant } \\
\text { bacteria }\end{array}$ & Source \\
\hline & Group B & & & \\
\hline & $\begin{array}{l}\text { Streptococcus } \\
\text { pneumoniae/Group A/ } \\
\text { Group B }\end{array}$ & $\begin{array}{l}\text { Streptococcus } \\
\text { pneumoniae UoS2029 }\end{array}$ & N/A & $\begin{array}{l}\text { This } \\
\text { study }\end{array}$ \\
\hline & $\begin{array}{l}\text { Streptococcus } \\
\text { pneumoniae/Group A/ } \\
\text { Group B }\end{array}$ & $\begin{array}{l}\text { Streptococcus } \\
\text { thermophilus NCTC } \\
12958\end{array}$ & N/A & $\begin{array}{l}\text { This } \\
\text { study }\end{array}$ \\
\hline & $\begin{array}{l}\text { Streptococcus } \\
\text { pneumoniae/Group A/ } \\
\text { Group B }\end{array}$ & $\begin{array}{l}\text { Streptococcus } \\
\text { pneumoniae Zo } 18 \text { m39- } \\
2\end{array}$ & N/A & $\begin{array}{l}\text { This } \\
\text { study }\end{array}$ \\
\hline
\end{tabular}

was also found to be hydrophobic (Fig. S3). Both families also have a notable polybasic region (residues 52-65 in family $i$ and 14-19 in ii) which produces two hydrophilic troughs.

Despite not fitting into any direct phylogenetic subfamilies within family ii, Bacillus pumilus GM3FR, Paeniclostridium sordellii R26833 and Bacillus thuringiensis serovar indiana HD521 all match the hydrophobic profile of family ii. Sequence logos (Fig. S4) showed high levels of conservation within the ii family, while i had high levels of conservation at the $\mathrm{N}$ and $\mathrm{C}$ termini. The conserved termini may be implicated as a ligation motif, allowing circularisation of the $\mathrm{C}$ and $\mathrm{N}$ termini.

\section{Gene cluster analysis}

To determine the number of putatively functional circular bacteriocins, each putative cluster was compared to the cluster of its most closely related experimentally confirmed circular bacteriocin (Fig. S5). A cluster was determined 'putatively functional' if it contained matching genes required for circular bacteriocin production of its phylogenetically closest relative. Table 3 shows a summary of this analysis.

Though there was high cluster divergence between families, similar genes were found in clusters in almost every case, but not limited to: ABC transporters, putative immunity gene/s, transmembrane proteins, SpoIIM proteins, permeases etc. Table S1 shows a general summary across the identified subfamilies. This provided more evidence that most of these putative sequences were circular bacteriocins, in line with the sequence similarity and hydrophobic profile results. Different gene clusters showed different degrees of similarity, with many having gene rearrangements, inversions, insertions and sharing low sequence similarities between homologues.

Several bacteriocin clusters appeared incomplete (Fig. S5) and it is probable that some of these clusters were vestigial or pseudogenes. Of the total 119 circular bacteriocin clusters, a conservative estimate of 90 (75.6\%) were putatively functional (Fig. S1), though the number

Table 3 Summary results of the mature bacteriocin sequence and gene cluster analysis

\begin{tabular}{llll}
\hline & Characteristic & No. of circular bacteriocins & Percentage of bacteriocins (\%) \\
\hline Mature bacteriocin sequence & Total circular bacteriocins & 119 & 100.0 \\
& Experimentally-confirmed & 20 & 16.8 \\
& Total identified in this study & 99 & 83.2 \\
& Containing polybasic region & 111 & 93.3 \\
& Containing aromatic residues & 115 & 96.6 \\
& Family i & 90 & 74.8 \\
Bacteriocin cluster & Family ii & 29 & 24.4 \\
& Predicted functional (conservative) & 90 & 75.6 \\
& Translational coupling & 109 & 91.6 \\
& Chrosomosomally-located & 77 & 64.7 \\
& Plasmid-associated & 25 & 21.0 \\
\hline
\end{tabular}




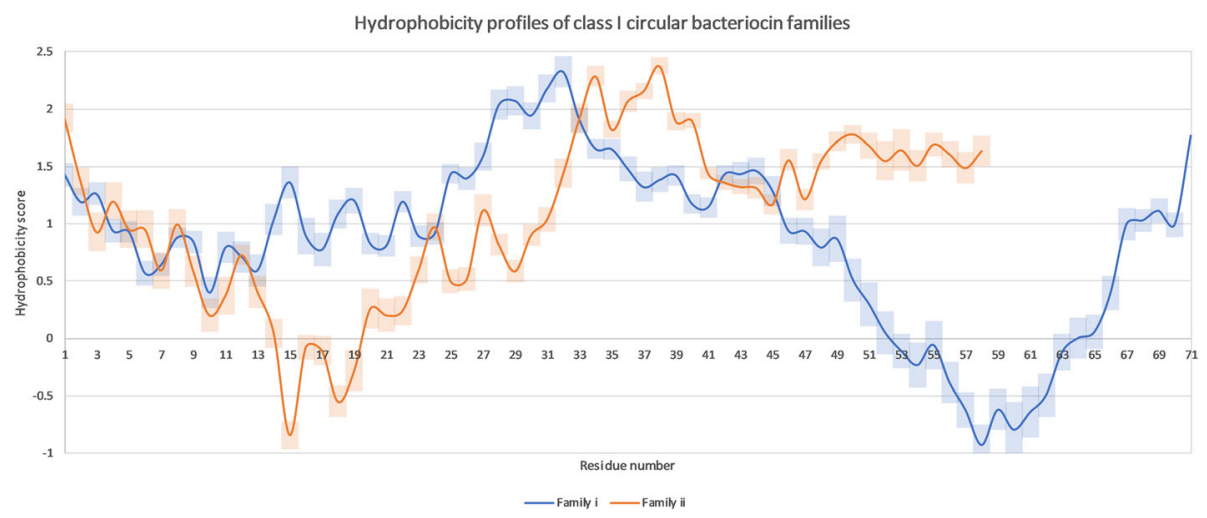

Fig. 3 Hydrophobicity profiles of two circular bacteriocin families. The blue lines shows family $i$ and the orange line shows ii. The semitransparent bars show the $95 \%$ confidence intervals. Hydrophobicity scores were calculated based on Kyte and Doolittle with a sliding window of $9[51]$

is likely higher due to the percentage of gene clusters which contain translational coupling (91.6\%). As this analysis was restricted by limited sequence data and assemblies, other genes outside the clusters required for circular bacteriocin production may be present elsewhere in the genome. These would be functional but would be scored as non-functional via this analysis. ABC transporters were seen in every single experimentally confirmed circular bacteriocin cluster, as well 95/99 of putatively identified clusters (Figs. S1, S5). This indicates that these 4 circular bacteriocins without $\mathrm{ABC}$ transporters were either inactive vestigial remnants or exported via another $\mathrm{ABC}$ transporter. Circular bacteriocin $A B C$ transporters are highly similar to $A B C$ transporters within the genomes. It was unclear if non-cluster transporters would be involved in production of circular bacteriocins and were thus considered putatively nonfunctional. HlyD-like and efflux RND transporters were only present in a few clusters within subfamilies and were not indicative of a putatively functional cluster, as previously demonstrated [52]. The clusters from C. polysaccharolyticum DSM 1801 and L. bacterium 3-1 acPFp are examples of unambiguously disrupted gene clusters which would most likely be non-functional. The summary of the cluster analysis for each putative circular bacteriocin (functional/non-functional) is found in (Fig. S1 and Table 3).

$21 \%$ of the clusters were found on plasmids, $64.7 \%$ were chromosomally located, and the remaining $13.6 \%$ were considered unknown (Table 3). 20.2\% were associated with mobile genetic elements such as insertion sequences (Fig. S5).

In the AS-48 subfamily (Fig. 4), six genes as$48 A B C C 1 D D 1$ have been shown to be essential for AS48 production [52]. This consists of the bacteriocin structural gene, a short and long putative membrane protein/stage II sporulation protein $\mathrm{M}$, another putative transmembrane protein, an $\mathrm{ABC}$ transporter and an immunity gene [52]. All six genes were found in most clusters, though putative immunity genes were not identified in 3/10 clusters. This analysis revealed stage II sporulation protein $\mathrm{M}$ domains were commonly found in the putative membrane proteins of the identified circular bacteriocin clusters. Other times, they were found encoded by two separate genes (Fig. 4). Therefore, they were treated as similar genes.

Immunity genes from clusters of experimentally confirmed circular bacteriocins appear to have two to three transmembrane domains (Fig. S3). They also contain large hydrophilic region/s which occur between these domains. Acidic residues were also found outside these transmembrane domains in 10/15 experimentally-confirmed circular bacteriocin immunity genes. There were no cysteine pairs found in the immunity genes except for in the atypical lycD sequence from leucocyclicin $\mathrm{Q}$.

To demonstrate the identification of putative circular bacteriocin subfamilies, which were most likely functional, cluster analysis of the putative bacillocyclin subfamily is shown in Fig. S6. Five of the six gene clusters match the gene cluster profile of the AS- 48 subfamily (closest phylogenetic relative) and appear to be intact.

Another previously undescribed observation was that some strains contained multiple structural bacteriocin genes within the same cluster (Fig. 5). Bacillus cereus BCE-01 (NZ_MVPV01000042.1) contained two different circularin-like circular structural bacteriocin genes with $82.89 \%$ identity. $80 \%$ identity was found between the signal sequences of these two structural genes. Bacillus thuringiensis AFS079576 (NZ_NUXU01000032.1) also contained two circularin-like structural genes with $81.58 \%$ identity within the same cluster. $80 \%$ identity was found between the signal sequences of these two structural genes. Bacillus weihenstephanensis SDA NFFE664 (NZ_FMBF01000026.1) contained three 


\section{Conserved putative circular bacteriocin gene clusters within the AS-48 subfamily}

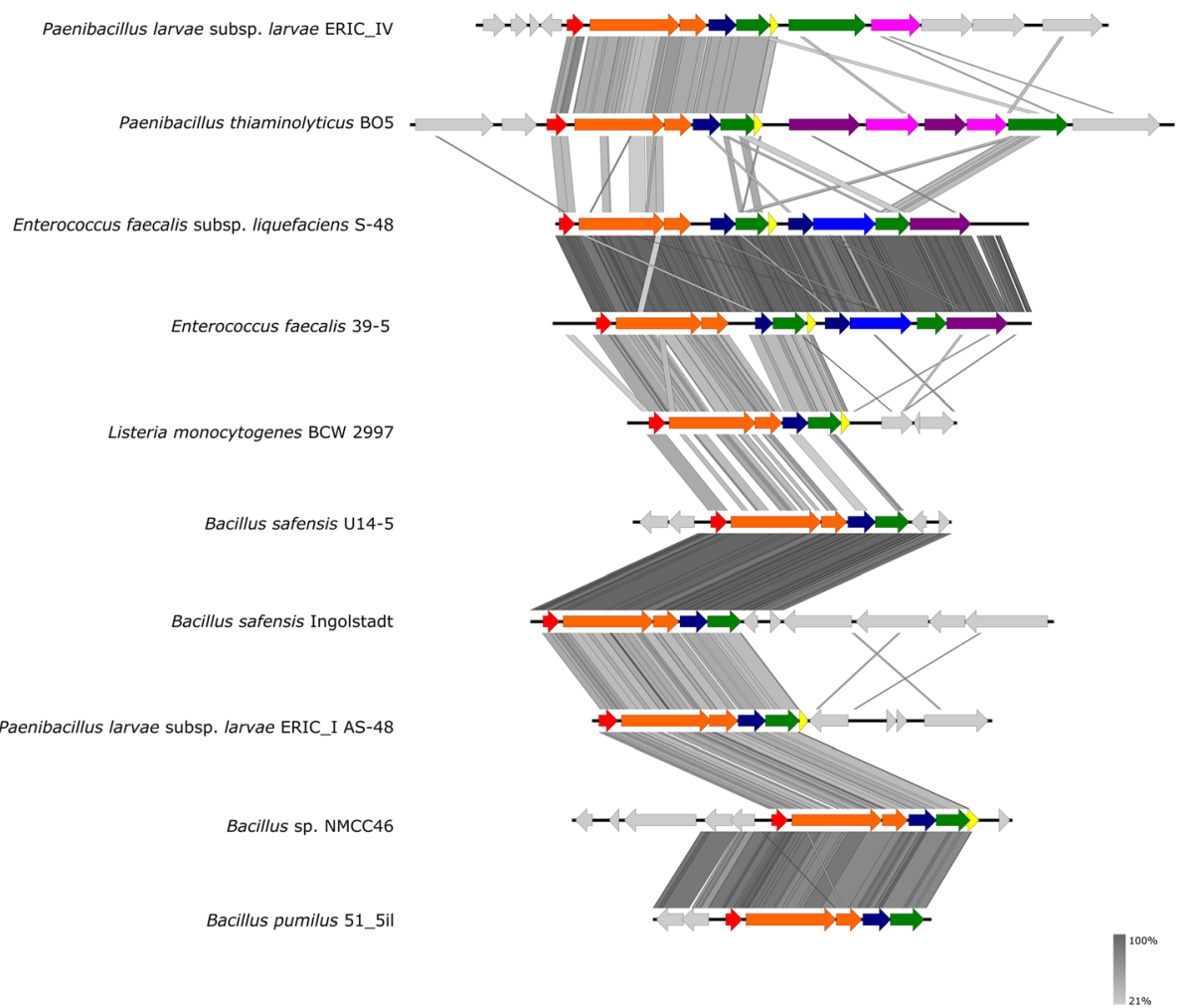

Fig. 4 Diagram showing the conserved genes within the AS-48 subfamily. Arrows show putative genes within the gene cluster. Red shows the bacteriocin structural gene. Orange shows putative membrane proteins/stage II sporulation protein $\mathrm{M}$. Yellow shows putative immunity genes such as-48D1. Green shows putative ABC-transporter proteins such as as-48D and as-48G. Blue shows HlyD/efflux RND transporters such as as-48F. Dark blue shows other transmembrane proteins. Pink shows putative binding-protein-dependent proteins and extracellular solute-binding proteins. Purple shows ABC-II/FtsX permeases such as-48H, based on work done with AS-48 [53]. Grey shows genes of unknown function which may or may not be related to circular bacteriocin production. Figure produced in Easyfig and Inkscape

\section{Conserved gene clusters between multi-structural circular} bacteriocin gene clusters

Bacillus thuringiensis AFS079576

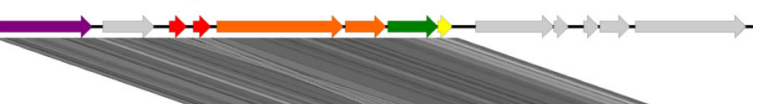

Bacillus cereus BCE-01

Bacillus weihenstephanensis SDA_NFFE664

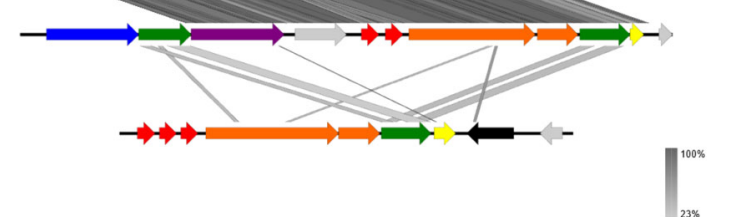

Fig. 5 Diagram of circular bacteriocin gene clusters with multiple structural genes. Arrows show putative genes within the gene cluster. $B$. weihenstephanensis SDA_NFFE664 contains three structural genes spaced with independent promoters, while B. cereus BCE-01 and B. thuringiensis AFS079576 contain two. Red shows bacteriocin structural genes. Orange shows putative membrane proteins/stage II sporulation protein M. Yellow shows putative immunity. Green shows putative ABC-transporter proteins. Blue shows HylD/efflux RND transporters. Purple shows ABC-II/ FtsX permeases. Black shows mobile genetic elements such as phage proteins/transposons/IS elements. Grey shows genes of unknown function which may or may not be related to circular bacteriocin production. Figure produced in Easyfig and Inkscape 
uberolysin-like circular structural genes with $100 \%$ identity and $92 \%$ identity, respectively. Each circular bacteriocin structural gene from $B$. weihenstephanensis SDA NFFE664 had identical signal sequences to the others in the cluster.

Each structural gene within these multi-structural gene clusters had independent putative promoters. Another observation is that a single putative immunity gene was found within these clusters, indicating it is most likely the single immunity factor for each circular bacteriocin variant.

\section{Discussion}

\section{Putatively functional circular bacteriocins}

This study shows that circular bacteriocins are much more prevalent than originally expected [39]. Previous bioinformatics efforts have identified uncharacterised novel circular bacteriocins $[28,30]$. Through the use of the mature sequences only, we have identified a large number of previously undescribed putatively circular bacteriocins. This approach differs from BAGEL which also includes signal sequences [54]. Although no sequence is publicly available, a circular bacteriocin was likely isolated from Lactobacillus acidophilus IBB 801 [55]. Some circular bacteriocins identified here have $100 \%$ similarity to other circular bacteriocins despite being present in different species. This study has shown bacteria from a wide range of sources including milk, soil, urine, plant cores, honeybee larvae, deep sea water and more (Fig. S1), contain putatively functional circular bacteriocin clusters. This indicates a potentially large reservoir of circular bacteriocin-producing strains and circular bacteriocins which could be used as therapeutics, food preservatives [39], or in other applications such as use as vector proteins to stabilise bioactive proteins [56]. There are many bioactive peptides which report low stability [57], which could be stabilised with C$\mathrm{N}$ terminal ligation [58] found in circular bacteriocins. During the process of this manuscript being written, circular bactercion amylocyclicin CMW1 was discovered [20]. This sequence was successfully predicted as a circular bacteriocin from this dataset, appearing in Bacillus amyloliquefaciens LL3. This co-occurrence provides more evidence that the predicted circular bacteriocins are likely correctly identified.

Bacillus spp. also contained the largest range of putative circular bacteriocins in this dataset. They contained clusters from family i subfamilies: AS-48, amylocyclicin, enterocin NKR-5-3B, uberolysin, lactocyclin/leucocyclin, circularin, bacillocyclin, krulwicyclin. They also contained family ii circular bacteriocins which were not assigned subfamilies. However, this may have been due to their phylogenetic heterogeneity, some of which has been remediated though reclassifications based on next generation sequencing rather than phenotype $[59,60]$.

The percentage of gene clusters which contain translational coupling $(91.6 \%)$ is most likely a better representation of functional clusters than the conservative prediction based on gene presence (75.6\%) found in Table 3. Translational coupling indicates a high level of cluster structure conservation [61] and it would be highly unusual for these genes to be asserting such a high degree of organisational structure if they were not positively-selected for, that is if they were not functional/expressed. Mutations in these tightly-packed clusters will not only alter the ends of particular gene products, but also impact transcription of downstream genes in alternative reading frames.

Presence of polybasic and aromatic residues were locationally conserved, found in 93.3 and $96.6 \%$ of identified circular bacteriocins, respectively (Table 3, Fig. S1). Aromatic residues are often found flanking transmembraneassociated helices, allowing penetration into membranes [62, 63]. Trp24 has been shown to be essential in the biological activity of AS-48, as it is located in a hydrophobic region that interacts with the membrane [64].

It has been previously pointed out that circular bacteriocins have similar hydrophobicity profiles [5]. Analysis of hydrophobicity profiles allowed increased confidence in the identification of putative circular bacteriocins discerned through sequence similarity. Hydrophobic profiles were maintained within subfamilies, as well as more generally within the families $\mathrm{i}$ and ii. By comparing profiles of putatively identified sequences to the average profile of each family, it can be determined which family they belong to. This could also be used to screen out non-circular bacteriocins. Though the hydrophobicity profiles are different between the families $i$ and ii, if the profile of ii is flipped, the profile is surprisingly similar to family i (Fig. S3). There are particular sequences which show divergence to the profiles, such as L. mesenteroides TK41401 (leucocyclicin Q) and Lactococcus sp. QU 12 (lactocyclicin Q) from family i, and Trichococcus alkaliphilus B5 (paracyclicin subfamily) and Alkalibacterium AK22 (akalicyclin subfamily) from ii.

A hydrophilic region was found in every putative and experimentally confirmed circular bacteriocin (Fig. 3, Fig. S3). This usually overlapped with the uni/polybasic region and implied a conserved functional region. There is strong evidence for a similar mechanism of action for this region, given the high levels of evolutionary conservation. This region is most likely involved with cell membrane interaction and binding based on the positively-charged basic residues and the negativelycharged cell membrane $[65,66]$. In experiments, the positively-charged (and polybasic) region of AS-48 (residues 49-69) showed no killing activity, but showed 
competitive binding to the negatively-charged membrane against the wild type AS-48 bacteriocin [65], indicating the role this region plays in the bactericidal activity of circular bacteriocins. Butyrivibriocin AR10 uncharacteristically does not contain a polybasic region (only a single basic residue), yet is functional as a circular bacteriocin against other B. fibrisolvens isolates [67]. It has a hydrophobic profile with a hydrophilic region which is consistent with family ii. This indicates polybasic regions aren't necessarily required for antimicrobial activity, but the hydrophilic region is.

\section{Phylogenetics}

Phylogenetic classification has resolution trade-offs. A higher number of families (reasonably up to 6) could have been attributed, though due to the similar proposed modes of action [17, 39] and conserved structural motifs [11, 30, 34, 35], further familial division would result in diminished returns. By classifying circular bacteriocins into groups with higher resolution such as subfamilies, experimentally-confirmed circular bacteriocins can be used as type-sequences and accurate sequence analysis and comparisons can be performed. This reduces the background noise of distantly-related circular bacteriocins within the immediate sequence family. It is highly probable that the putative circular bacteriocins within each subfamily share a similar mechanism of action but have their own distinct spectrum of activity. The phylogenetic classifications were further enforced by cluster analysis. For example, uberolysin and amylocyclicin circular bacteriocin subfamilies are distinct at the cluster level, have different hydrophobicity profiles at their C termini (Fig. S3), yet are not divergent regarding structural gene homology despite a size difference of 6 residues.

\section{Conserved genes within circular bacteriocin clusters}

Cluster analysis proved to be informative for determining putative functional circular bacteriocins, as well as phylogenetic classification. Recently-diverged structural genes would most likely have similar associated genes within their bacteriocin clusters. The drawback of this type of analysis was the associated genes essential for circular bacteriocin product may not be present within the same cluster but elsewhere within the genomic material. However, given a conservative $75.6 \%$ estimate of putative functionality, a number of potentially useful antimicrobial peptides have been highlighted. It is probable that some of these clusters contain non-functional pseudogenes, but given that most clusters were 'intact' upon comparison to experimentally confirmed clusters, the genes are considered conserved for circular bacteriocin production $[2,4,18,19,21-23,25-27,29-33,38$, $41,52,68,69]$.
Stage II sporulation protein $\mathrm{M}$ membrane proteins were found in almost every identified cluster, indicating they are an essential gene and their absence was considered for putative cluster functionality. This observation has been previously observed [70]. SpoIIM proteins likely form a protein-protein complex with the $A B C$ transporter, acting as the membrane spanning domain as the $A B C$ transporter proteins do not contain any transmembrane domains. Mature circularised bacteriocin accumulated within cells when the DUF95 superfamily protein (SpoIIM) was removed within leucocyclicin Q gene cluster [38]. This indicates posttranslational circularisation occurs internally before export. The $\mathrm{ABC}$ transporter was unable to secrete the bacteriocin as it was not anchored at the membrane.

Strains with multi-structural gene clusters are an undescribed phenomenon until now. Given their high sequence identities to each other, it is clear they are a result of duplication events in which slight variants with independent promoters have been selected for. It is most likely that these strains swap or co-express variable circular bacteriocins via response regulators and quorum sensing [29, 31, 71], allowing expression of different circular bacteriocins with a slightly different spectrum of activity/microbial targets. These multi-structural gene clusters can also give us insights into the putative immunity genes. It appears one putative immunity gene is enough to provide protection against each circular bacteriocin variant within the cluster. This indicates immunity genes may provide broader immunity than once thought and may possibly provide immunity to similar circular bacteriocins with as low as $\sim 80 \%$ similarity. Based on the presence of two (sometimes three) putative transmembrane domains, as well as the central hydrophilic region and presence of acidic residues at the termini, the mechanism of immunity can be proposed. Immunity proteins may function as transmembrane proteins and competitively bind positively-charged/polybasic regions of corresponding circular bacteriocins, thus reducing pore formation within the cell membrane. Acidic residues found in the immunity proteins may compete with the negatively-charged cell membrane. Though, further experimental analysis is required, as immunity has been shown to be a cumulative effect with other genes within the cluster demonstrating a role in immunity [38, $41,53]$. More broadly, the observation that immunity genes are present in most gene clusters indicates these bacteria are susceptible to their own bacteriocins. Therefore, related species may also prove susceptible if lacking the corresponding immunity gene. This is hopeful as circular bacteriocins identified here were found in Enterococcus, Staphylococcus and Streptococcus species, which are currently regarded by the WHO as priority organisms for discovery of new antimicrobials [44]. 


\section{Selfish genetic elements}

Although providing fitness to the cell, circular bacteriocins and their associated clusters can be thought of as selfish genetic elements. Given the high stability of circular bacteriocins, if at any time the cluster is mutated or plasmid is lost, the immunity factors associated with the cluster may also be lost. The ex-producer would then be susceptible to the bacteriocin, and therefore this phenotype will be selected against. Also, given the high temporal stability of circular bacteriocins, they would also be more stable than the immunity genes which would be more susceptible to proteases, heat, $\mathrm{pH}$ etc., and would require continual renewal via gene expression. By nature, it is a toxinantitoxin system which locks the producing strain into a long-term partnership. It has been demonstrated by removing the circular bacteriocin gassericin A from a plasmid, segregational stability of that plasmid drops [72]. This explains why so many of the circular bacteriocin clusters identified were putatively intact (Table 3), regardless if they are chromosomally associated or plasmidborne. As previously described, the spectrum of antimicrobial activity (usually to closely related species) of circular bacteriocins provides further evidence of the toxinantitoxin relationship [22, 24, 72]. Coincidentally, the circular bacteriocin from L. nodensis DSM 19682 was previously highlighted by a similar genome-mining study and the strain was not found to demonstrate antimicrobial activity against a range of bacteria including Enterococci and Lactobacilli [32]. Given that the gene cluster was identified as intact (Fig. S1, Fig. S5), it is possible the bacteriocin was not tested against closely-related strains (including $L$. nodensis) which may demonstrate susceptibility.

A circular bacteriocin cluster missing only an immunity gene has several explanations and may still potentially be active despite missing a putative immunity gene (though not considered 'putatively active' in this study). Production of the circular bacteriocin without immunity factors generally results in self-killing [4]. The first explanation is that the bacteriocin is not functionally expressed. Alternatively, if the antimicrobial activity mode of action relies on specific target receptors not found in the producer strain as in the case of Garvicin ML [12], immunity genes would not be needed, as lacking the target gene would be enough to confer immunity. Another alternative explanation is recent inactivation of the entire immunity-gene-lacking cluster, which given enough time will eventually be reduced to pseudogenes and vestigial fragments. Being associated with conjugative plasmids or mobile genetic elements (Table 3) such as transposons allows wider dissemination of these genes within populations.

\section{Conclusions}

This work has identified 94 novel and previously undescribed circular bacteriocins utilising known translated
DNA sequences of mature bacteriocins. A small number of these sequences have been previously described by bioinformatic approaches [28], however other sequences identified in this work were either incorrectly annotated in publicly available databases or not annotated at all. All sequences were found in Gram positive bacteria. Phylogenetic analysis allowed clustering of these bacteriocins into two families (i and ii) which is consistent with previous literature. To further evaluate these bacteriocin sequences as legitimate, sequences were classified into subfamilies based off sequence similarity to experimentally confirmed circular bacteriocins. These subfamilies were confirmed by comparing the bacteriocin gene clusters of experimentally-confirmed circular bacteriocins. The cluster analysis was highly consistent with the mature bacteriocin sequence phylogeny clustering. Almost all gene clusters were also found to have translational coupling. This analysis was also able to demonstrate the minimum essential genes required for circular bacteriocin production and secretion, allowing identification of putatively active bacteriocin clusters. Classification of the bacteriocins into subfamilies allowed high resolution sequence analysis which can be used to identify important residues, motifs, inform mutagenesis studies and synthetic design of future circular antimicrobial proteins.

Analysis of the mature bacteriocin sequences revealed several important motifs which were consistent across almost every sequence identified within the two families and within each subfamily. These motifs were locationally consistent within but not between the two families. Motifs include conserved $\mathrm{C}$ and $\mathrm{N}$ termini within subfamilies, sequence length, consistent hydrophobic profiles (Fig. 3) despite sequence dissimilarity, a polybasic region likely involved in membrane binding and aromatic residues flanking transmembrane-associated helices likely involved in membrane penetration. The presence of these motifs across two independent families of this class of antimicrobial indicates their importance in expression and activity of circular bacteriocins.

Finally, the gene cluster analysis revealed almost every circular bacteriocin cluster contained immunity genes. This indicates the antimicrobial activity is also likely active against the producer strain, as part of a toxin-antitoxin system. This realisation allows genome mining to perform a targeted approach to combat pathogens, namely as the bacteriocins are active against the producer strain. We identified putatively active circular bacteriocin clusters from high priority pathogens Staphylococcus, Streptococcus and Enterococcus species which should be active against clinically relevant strains. Future work should involve the isolation of these producer bacteria (Table 2) and screening their culture supernatants against clinical isolates to characterise and identify these bioinformatically identified antimicrobials. 


\section{Methods}

\section{Identification of putative circular bacteriocins}

NCBI was mined (date accessed: 20/2/19) against the 17 known mature circular bacteriocin sequences minus signal sequences.

\section{Phylogenetic analysis of putative circular bacteriocins} Clustal Omega (https://www.ebi.ac.uk/Tools/msa/clustalo/) (date accessed 25/2/19) [73] was used for alignments and exported to fasta format, which was used as input for RAxML (raxmlHPC-PTHREADS-SSE3 version 8.2.10) [74] using the following parameters for $\mathrm{ML}+$ rapid bootstrap analysis with 100 replicates:

-T 2 -f a $-\times 285$-m PROTGAMMABLOSUM62 -p $639-\mathrm{N} 100$.

The bipartitions output file was used in FigTree version 1.4.4 (http://tree.bio.ed.ac.uk/software/figtree/) for viewing/manipulation. Microsoft Excel version 1902 was used to compile the table of putative circular bacteriocin and characteristics, which was then manipulated using Inkscape version 0.92 (https://www.inkscape.org).

\section{Circular bacteriocin characteristics}

Polybasic residues were identified in the mature bacteriocin via the 'Mark' function in Notepad++ version 7.5.9 searching for the string " $\mathrm{R}|\mathrm{K}| \mathrm{H}$ " using the following search modifiers: 'Regular expression' and 'Match case'.

\section{Hydrophobicity analysis}

Hydrophobicity profiles were generated using the protscale website https://web.expasy.org/protscale/ with a sliding window of 9 [51]. 95\% confidence intervals were calculated using the Descriptive Statistics module from the Data Analysis ToolPak in Microsoft Excel. As C and $\mathrm{N}$ termini would be joined in the mature circular bacteriocin form, the first four residues were copied to the end of the sequence and the final four residues were copied to the beginning of the sequence to account for the sliding window of 9 . This was performed by searching the amino acid fasta file for: $\wedge\left(([\mathrm{A}-\mathrm{Z}]\{4\})\left([\mathrm{A}-\mathrm{Z}]^{* *}\right)([\mathrm{A}-\mathrm{Z}]\{4\})\right) \$$ and replacing with $\$ 4 \$ 1 \$ 2$ with search modifiers: 'Regular expression' and 'Match case' in Notepad++.

\section{Transmembrane domain analysis}

Sequences were submitted to Phobius [75] (date accessed: 1/3/19).

\section{Sequence logos}

Skylign (date accessed: 9/4/19) was used after Clustal Omega alignments using the 'Observed Counts', 'Alignment sequences are full length', and 'Information Content - All' parameters [76].

\section{Gene cluster analysis}

To determine if the circular bacteriocin structural gene and associated gene clusters were present on plasmids or chromosome, tBlastn and BLASTn (https://blast.ncbi. nlm.nih.gov/Blast.cgi) [77] was used to see if there were significant nucleotide hits to plasmids or chromosomes on NCBI. Size was also considered; if a gene cluster was on a contig $>100 \mathrm{~kb}$, it was considered most likely chromosomal. Functional domains were determined using HMMER version 3.2.1 (http://hmmer.org/) [78], along with NCBI annotations to infer gene function. Presence of plasmid-determinants such as repA/B and mobilisation genes were used to determine presence of cluster on plasmid. Presence of chromosomal determinants such as the $16 \mathrm{~s}$ and tRNA genes were used to infer chromosomal localisation. If location was unclear, they were determined as 'Unknown'.

For gene clusters broken up amongst multiple contigs, contigs containing cluster elements were first joined with $5 \mathrm{~N}$ 's, and then used for cluster alignments and analysis.

Easyfig version 2.2.3 [79] was used to align and visualise gene clusters using the tblastx function with an evalue cut-off of 0.001. Lactococcus sp. QU 12 was excluded from cluster analysis as only the structural gene sequence data is publicly available.

\section{Supplementary information}

Supplementary information accompanies this paper at https://doi.org/10. 1186/s12866-020-01772-0.

Additional file 1: Figure S1. Table containing further, detailed information of each circular bacteriocin.

Additional file 2: Figure S2. Phylogenetic tree showing the two subfamilies of circular bacteriocins. Family $i$ is shown in red, while ii is shown in blue.

Additional file 3: Figure S3. Raw data of hydrophobicity scores from each bacteriocin.

Additional file 4: Figure S4. Sequence logo generated using Skylign after Clustal Omega alignment. The top logo shows family i. The bottom logo shows family ii. Family i has a sequence length of 84 due to the sequence variation within the family, resulting in a gapped alignme.

Additional file 5: Figure S5. Series of figures showing the gene cluster analysis.

Additional file 6: Table S1. Summary of circular bacteriocin gene clusters and their general distribution throughout the circular bacteriocin subfamilies. Not every circular bacteriocin cluster within each subfamily was predicted to contain each of the genes here, though generally this was the case.

Additional file 7: Figure S6. Bacillocyclin subfamily cluster analysis. Diagram showing the conserved genes within the putative bacillocyclin subfamily. Arrows show putative genes within the gene cluster. Red shows the bacteriocin structural gene. Orange shows putative membrane proteins/stage II sporulation protein M. Yellow shows putative immunity genes such as-48D1. Green shows putative ABC-transporter proteins such as as-48D and as-48G. Blue shows HylD/efflux RND transporters such as as-48F. Dark blue shows other transmembrane proteins. Pink shows putative binding-protein-dependent proteins and extracellular solute-binding proteins. Purple shows ABC-II/FtsX permeases such as- $48 \mathrm{H}$, based off the 
work done with AS-48 [4]. Grey shows genes of unknown function which may or may not be related to circular bacteriocin production. Figure produced in Easyfig and Inkscape.

\section{Acknowledgments}

This research received no specific grant from any funding agency in the public, commercial, or not-for-profit sectors

\section{Authors' contributions}

Analysis performed by BV. Experimental design by BV, BHAR and ATS. All authors read and approved the final manuscript.

\section{Funding}

This work was funded by Griffith University. Dr. Ben Vezina was in receipt of a research fellowship from Griffith University.

\section{Availability of data and materials}

All data generated or analysed during this study are included in this published article [and its supplementary information files].

\section{Ethics approval and consent to participate}

Not applicable.

\section{Consent for publication}

Not applicable.

\section{Competing interests}

The authors declare that the research was conducted in the absence of any commercial or financial relationships that could be construed as a potentia conflict of interest.

\section{Received: 14 October 2019 Accepted: 29 March 2020}

Published online: 06 April 2020

\section{References}

1. Acedo JZ, et al. The expanding structural variety among bacteriocins from gram-positive bacteria. FEMS Microbiol Rev. 2018;42(6):805-28.

2. Kawai Y, et al. Gassericin a; an uncommon cyclic Bacteriocin produced by Lactobacillus gasseriLA39 linked at N- and C-terminal ends. Biosci Biotechnol Biochem. 1998;62(12):2438-40

3. Samyn B, et al. The cyclic structure of the enterococcal peptide antibiotic AS-48. FEBS Lett. 1994:352(1):87-90

4. Borrero J, et al. Plantaricyclin a, a novel circular Bacteriocin produced by Lactobacillus plantarum N1326: purification, characterization, and heterologous production. Appl Environ Microbiol. 2018;84(1):e01801-17.

5. Kawai $Y$, et al. The circular Bacteriocins Gassericin a and Circularin a. Curr Protein Pept Sci. 2004;5:393-8.

6. Montalbán-López M, et al. Characterization of linear forms of the circular enterocin AS-48 obtained by limited proteolysis. FEBS Lett. 2008;582(21-22): 3237-42.

7. Sánchez-Hidalgo M, et al. AS-48 bacteriocin: close to perfection. Cell Mo Life Sci. 2011;68(17):2845-57.

8. Gálvez A, et al. Permeation of bacterial cells, permeation of cytoplasmic and artificial membrane vesicles, and channel formation on lipid bilayers by peptide antibiotic AS-48. J Bacteriol. 1991;173(2):886.

9. Kawai $Y$, et al. Structural and functional differences in two cyclic Bacteriocins with the same sequences produced by lactobacilli. Appl Environ Microbiol. 2004;70(5):2906

10. Gong X, et al. The circular bacteriocin, carnocyclin a, forms anion-selective channels in lipid bilayers. Biochim Biophys Acta Biomembr. 2009;1788(9): 1797-803.

11. Himeno $\mathrm{K}$, et al. Identification, characterization, and three-dimensional structure of the novel circular Bacteriocin, Enterocin NKR-5-3B, from Enterococcus faecium. Biochemistry. 2015:54(31):4863-76.

12. Gabrielsen $C$, et al. The maltose $A B C$ transporter in Lactococcus lactis facilitates high-level sensitivity to the circular Bacteriocin Garvicin ML. Antimicrob Agents Chemother. 2012;56(6):2908.

13. Bastos MdCdF, Coelho MLV, Santos OCdS. Resistance to bacteriocins produced by Gram-positive bacteria. Microbiology. 2015;161(4):683-700.
14. Perez RH, Zendo T, Sonomoto K. Novel bacteriocins from lactic acid bacteria (LAB): various structures and applications. Microb Cell Factories. 2014;13(1):S3

15. Jiménez JJ, et al. Cloning strategies for heterologous expression of the bacteriocin enterocin A by Lactobacillus sakei Lb790, Lb. plantarum NC8 and Lb. casei CECT475. Microb Cell Fact. 2015;14(1):166.

16. Cotter PD, Hill C, Ross RP. Bacteriocins: developing innate immunity for food. Nat Rev Microbiol. 2005:3:777.

17. Gabrielsen C, et al. Circular Bacteriocins: biosynthesis and mode of action. Appl Environ Microbiol. 2014;80(22):6854.

18. Potter A, et al. The gene cluster of aureocyclicin 4185: the first cyclic bacteriocin of Staphylococcus aureus. Microbiology. 2014;160(5):917-28.

19. Scholz R, et al. Amylocyclicin, a novel circular Bacteriocin produced by Bacillus amyloliquefaciens FZB42. J Bacteriol. 2014;196(10):1842.

20. Kurata $A$, et al. Characterization and heterologous expression of an antimicrobial peptide from Bacillus amyloliquefaciens CMW1. Biotechnol Biotechnol Equip. 2019:33(1):886-93.

21. Tomita $\mathrm{H}$, et al. Cloning and genetic and sequence analyses of the bacteriocin 21 determinant encoded on the Enterococcus faecalis pheromone-responsive conjugative plasmid pPD1. J Bacteriol. 1997;179(24):7843.

22. Martin-Visscher LA, et al. Isolation and characterization of carnocyclin a, a novel circular bacteriocin produced by Carnobacterium maltaromaticum UAL307. Appl Environ Microbiol. 2008:74(15):4756-63.

23. Kemperman $\mathrm{R}$, et al. Identification and characterization of two nove Clostridial Bacteriocins, Circularin a and Closticin 574. Appl Environ Microbiol. 2003;69(3):1589.

24. Egan K. Discovery and evaluation of novel and characterised bacteriocins for future applications. In: School of Microbiology. Cork, Ireland: University College Cork; 2018.

25. Borrero J, et al. Characterization of Garvicin ML, a Novel Circular Bacteriocin Produced by Lactococcus garvieae DCC43, Isolated from Mallard Ducks (Anas platyrhynchos). Appl Environ Microbiol. 2011;77(1):369.

26. Sawa N, et al. Identification and characterization of Lactocyclicin $\mathrm{Q}$, a novel cyclic Bacteriocin produced by Lactococcus sp. strain QU 12. Appl Environ Microbiol. 2009;75:1552-8.

27. Masuda Y, et al. Identification and characterization of Leucocyclicin $\mathrm{Q}$ a novel cyclic Bacteriocin produced by Leuconostoc mesenteroide TK41401. Appl Environ Microbiol. 2011;77(22):8164.

28. van Heel AJ, et al. Genome-guided identification of novel head-to-tail cyclized antimicrobial peptides, exemplified by the discovery of pumilarin. Microbial Genomics. 2017;3(10):1-9.

29. Wirawan RE, et al. Uberolysin: a novel cyclic bacteriocin produced by Streptococcus uberis. Microbiology. 2007;153(5):1619-30

30. Acedo JZ, et al. Solution structure of Acidocin B, a circular Bacteriocin produced by Lactobacillus acidophilus M46. Appl Environ Microbiol. 2015; 81(8):2910.

31. Kalmokoff ML, et al. Butyrivibriocin AR10, a new cyclic bacteriocin produced by the ruminal anaerobe Butyrivibrio fibrisolvens AR10: characterization of the gene and peptide. Can J Microbiol. 2003:49(12):763-73.

32. Collins FWJ, et al. Bacteriocin gene-trait matching across the complete Lactobacillus pan-genome. Sci Rep. 2017;7(1):3481.

33. Golneshin A. Characterisation of bacteriocin genes and proteins from Lactobacillus plantarum B21 as potential new antimicrobial agents and natural food preservatives in School of Applied Sciences. Australia: RMIT University; 2014

34. Martin-Visscher LA, et al. The three-dimensional structure of Carnocyclin a reveals that many circular Bacteriocins share a common structural motif. Biol Chem. 2009:284(42):28674-81.

35. González C, et al. Bacteriocin AS-48, a microbial cyclic polypeptide structurally and functionally related to mammalian NK-lysin. Proc Natl Acad Sci. 2000;97(21):11221

36. Maqueda $\mathrm{M}$, et al. Genetic features of circular bacteriocins produced by gram-positive bacteria. FEMS Microbiol Rev. 2008;32(1):2-22.

37. Cebrián $\mathrm{R}$, et al. Insights into the functionality of the putative residues involved in Enterocin AS-48 maturation. Appl Environ Microbiol. 2010;76(21):7268.

38. Mu F, et al. Biological function of a DUF95 superfamily protein involved in the biosynthesis of a circular bacteriocin, leucocyclicin Q. J Biosci Bioeng. 2014;117(2):158-64.

39. Perez RH, Zendo T, Sonomoto K. Circular and Leaderless Bacteriocins: Biosynthesis, Mode of Action, Applications, and Prospects. Front Microbiol. 2018;9(2085) 
40. Perez RH, et al. Mutations near the cleavage site of enterocin NKR-5-3B prepeptide reveal new insights into its biosynthesis. Microbiology. 2017; 163(4):431-41.

41. Perez $\mathrm{RH}$, et al. Functional analysis of genes involved in the biosynthesis of Enterocin NKR-5-3B, a novel circular Bacteriocin. J Bacteriol. 2016;198(2):291.

42. von Heijne $G$, Abrahmsèn L. Species-specific variation in signal peptide design implications for protein secretion in foreign hosts. FEBS Lett. 1989; 244(2):439-46.

43. Thage BV, et al. Purification and characterization of a branched-chain amino acid aminotransferase from Lactobacillus paracasei subsp. paracasei CHCC 2115. J Appl Microbiol. 2004;96(3):593-602.

44. WHO. WHO priority pathogens list for R\&D of new antibiotics, W.H. Organisation, Editor. 2017, Organisation: https://www.who.int.

45. Fujimoto $S$, et al. Physical mapping of the conjugative bacteriocin plasmid pPD1 of Enterococcus faecalis and identification of the determinant related to the pheromon response, vol. 177; 1995. p. 5574-81.

46. Gálvez A, et al. Characterization and partial purification of a broad spectrum antibiotic AS-48 produced by Streptococcus faecalis. Can J Microbiol. 1986; 32(10):765-71.

47. Martínez-Bueno M, et al. A transferable plasmid associated with AS-48 production in Enterococcus faecalis. J Bacteriol. 1990;172(5):2817.

48. Ishibashi $\mathrm{N}$, et al. Purification and characterization of multiple Bacteriocins and an inducing peptide produced by Enterococcus faecium NKR-5-3 from Thai fermented fish. Biosci Biotechnol Biochem. 2012;76(5):947-53.

49. Ceotto H, et al. Aureocins 4185, Bacteriocins produced by Staphylococcus aureus 4185: potential application in food preservation. Foodborne Pathog Dis. 2010;7(10):1255-62.

50. Ceotto $\mathrm{H}$, et al. Bacteriocin production by Staphylococcus aureus involved in bovine mastitis in Brazil. Res Microbiol. 2009;160(8):592-9.

51. Kyte J, Doolittle RF. A simple method for displaying the hydropathic character of a protein. J Mol Biol. 1982;157(1):105-32

52. Martínez-Bueno $\mathrm{M}$, et al. Analysis of the gene cluster involved in production and immunity of the peptide antibiotic AS-48 in Enterococcus faecalis. Mol Microbiol. 1998;27(2):347-58

53. Mercedes M, et al. Peptide AS-48: prototype of a new class of cyclic Bacteriocins. Curr Protein Pept Sci. 2004;5(5):399-416.

54. van Heel AJ, et al. BAGEL4: a user-friendly web server to thoroughly mine RiPPs and bacteriocins. Nucleic Acids Res. 2018:46(W1):W278-81.

55. Zamfir $\mathrm{M}$, et al. Purification and characterization of a bacteriocin produced by Lactobacillus acidophilus IBB 801. J Appl Microbiol. 1999;87(6):923-31.

56. Iwai H, Plückthun A. Circular $\beta$-lactamase: stability enhancement by cyclizing the backbone. FEBS Lett. 1999:459(2):166-72.

57. Espinosa-Hernández $\mathrm{E}_{\text {, et }}$ al. The insertion of bioactive peptides at the Cterminal end of an $11 \mathrm{~S}$ globulin changes the structural stability and improves the antihypertensive activity. Electron J Biotechnol. 2019;37:18-24.

58. Clark RJ, et al. Engineering stable peptide toxins by means of backbone cyclization: stabilization of the a-conotoxin MII. Proc Natl Acad Sci U S A 2005;102(39):13767.

59. Nazina TN, et al. Taxonomic study of aerobic thermophilic bacilli: descriptions of Geobacillus subterraneus gen. nov., sp. nov. and Geobacillus uzenensis sp. nov. from petroleum reservoirs and transfer of Bacillus stearothermophilus, Bacillus thermocatenulatus, Bacillus thermoleovorans, Bacillus kaustophilus, Bacillus thermodenitrificans to Geobacillus as the new combinations G. stearothermophilus, G. th. Int J Syst Evol Microbiol. 2001; 51(2):433-46.

60. Logan NA, et al. Proposed minimal standards for describing new taxa of aerobic, endospore-forming bacteria. Int J Syst Evol Microbiol. 2009:59(8):2114-21.

61. van de Guchte M, Kok J, Venema G. Distance-dependent translational coupling and interference in Lactococcus lactis. Mol Gen Genet MGG. 1991; 227(1):65-71.

62. Braun $P$, von Heijne $G$. The aromatic residues Trp and Phe have different effects on the positioning of a Transmembrane Helix in the microsomal membrane. Biochemistry. 1999;38(30):9778-82.

63. Gleason NJ, et al. Single tryptophan and tyrosine comparisons in the Nterminal and C-terminal Interface regions of Transmembrane GWALP peptides. J Phys Chem B. 2013;117(44):13786-94

64. Sanchez-Hidalgo M, et al. Conformational Stability and Activity of Circular Enterocin AS-48 Derivatives, vol. 17; 2010. p. 708-14.

65. Jiménez MA, et al. Design, NMR characterization and activity of a 21-residue peptide fragment of bacteriocin AS-48 containing its putative membrane interacting region, vol. 11; 2005. p. 29-36.
66. Kim J, et al. Binding of peptides with basic residues to membranes containing acidic phospholipids. Biophys J. 1991;60(1):135-48.

67. Kalmokoff ML, Teather RM. Isolation and characterization of a bacteriocin (Butyrivibriocin AR10) from the ruminal anaerobe Butyrivibrio fibrisolvens AR10: evidence in support of the widespread occurrence of bacteriocin-like activity among ruminal isolates of B. fibrisolvens. Appl Environ Microbiol. 1997;63:394-402.

68. Kawai $Y$, et al. DNA Sequencing and Homologous Expression of a Small Peptide Conferring Immunity to Gassericin A, a Circular Bacteriocin Produced by Lactobacillus gasseri LA39. Appl Environ Microbiol. 2009;75(5): 1324.

69. Belkum M, Martin-Visscher L, Vederas J. Cloning and characterization of the gene cluster involved in the production of the circular Bacteriocin Carnocyclin a. Probiotics Antimicrob Proteins. 2010;2:218-25.

70. van Belkum MJ, Martin-Visscher LA, Vederas JC. Structure and genetics of circular bacteriocins. Trends Microbiol. 2011;19(8):411-8.

71. Bartholomae $\mathbf{M}$, et al. Major gene-regulatory mechanisms operating in ribosomally synthesized and post-translationally modified peptide (RiPP) biosynthesis. Mol Microbiol. 2017;106(2):186-206.

72. Ito $Y$, et al. Conjugative plasmid from Lactobacillus gasseri LA39 that carries genes for production of and immunity to the circular Bacteriocin Gassericin a. Appl Environ Microbiol. 2009;75(19):6340.

73. Chojnacki $S$, et al. Programmatic access to bioinformatics tools from EMBLEBl update: 2017. Nucleic Acids Res. 2017;45(W1):W550-3.

74. Stamatakis A. RAxML version 8: a tool for phylogenetic analysis and postanalysis of large phylogenies. Bioinformatics. 2014;30(9):1312-3.

75. Krogh A, Sonnhammer ELL, Käll L. Advantages of combined transmembrane topology and signal peptide prediction—the Phobius web server. Nucleic Acids Res. 2007;35(suppl_2):W429-32.

76. Wheeler TJ, Clements J, Finn RD. Skylign: a tool for creating informative, interactive logos representing sequence alignments and profile hidden Markov models. BMC Bioinformatics. 2014;15(1):7.

77. NCBI. Database resources of the National Center for biotechnology information. Nucleic Acids Res. 2017:46(D1):D8-D13.

78. Luciani A, et al. HMMER web server: 2018 update. Nucleic Acids Res. 2018; 46(W1):W200-4

79. Sullivan MJ, Petty NK, Beatson SA. Easyfig: a genome comparison visualizer. Bioinformatics. 2011;27(7):1009-10.

\section{Publisher's Note}

Springer Nature remains neutral with regard to jurisdictional claims in published maps and institutional affiliations.

\section{Ready to submit your research? Choose BMC and benefit from:}

- fast, convenient online submission

- thorough peer review by experienced researchers in your field

- rapid publication on acceptance

- support for research data, including large and complex data types

- gold Open Access which fosters wider collaboration and increased citations

- maximum visibility for your research: over $100 \mathrm{M}$ website views per year

At $\mathrm{BMC}$, research is always in progress.

Learn more biomedcentral.com/submissions 